\title{
Assessing the Establishment and Implementation of Environmental Flows in Spain
}

\author{
Gabriel Mezger $\mathbb{B}^{1,2} \cdot$ Lucia De Stefano ${ }^{1,2} \cdot$ Marta González del Tánago ${ }^{3}$
}

Received: 13 March 2019 / Accepted: 25 October 2019

(c) Springer Science+Business Media, LLC, part of Springer Nature 2019

\begin{abstract}
The alteration of natural flows due to water withdrawals and the presence of hydraulic infrastructure poses significant threats to the integrity of riverine ecosystems. The establishment of environmental flows (EF) has been conceived as a water management tool to mitigate the impact of in-stream flows alteration. To date, a large body of literature has focused on methods to define EF, but less attention has been paid to documenting and assessing their actual implementation on the ground. This article provides a framework to describe and assess the process of design, application, and monitoring of EF at a river basin level. The framework is applied to Spain, where significant efforts have been made during the past decade to define and implement EF across the country. The goal of the paper is to identify strengths and opportunities for improving the implementation of EF at country level. The Spanish legislation establishes that EF should contribute to the achievement of the good ecological status of surface water bodies as required by the European Union Water Framework Directive. Several pitfalls in the design, application, and monitoring of this important river management measure constrain the ability of the existing EF to deliver that fundamental outcome.
\end{abstract}

Keywords Environmental flows $\cdot$ Assessment $\cdot$ Water Framework Directive $\cdot$ Adaptive management

\section{Introduction}

In recent years, several countries have included in their water laws strategies to ensure an adequate water provision for natural ecosystems through environmental flows (EF) (Acreman and Ferguson 2010). These include South Africa (Harwood et al. 2017), Tanzania (Acreman and Dunbar 2004), Costa Rica (Jiménez 2005), Australia, China, England, Mexico, the United States, Pakistan (Harwood et al.

Supplementary information The online version of this article (https:// doi.org/10.1007/s00267-019-01222-2) contains supplementary material, which is available to authorized users.

$\triangle$ Gabriel Mezger

gmezger@ucm.es

1 Departamento de Geodinámica, Estratigrafía y Paleontología, Facultad de Ciencias Geológicas, Universidad Complutense de Madrid, Madrid, España

2 Observatorio del Agua, Fundación Botín, Madrid, Spain

3 Departamento de Sistemas y Recursos Naturales, E. T. S. de Ingeniería de Montes, Forestal y del Medio Natural, Universidad Politécnica de Madrid, Madrid, España
2017), Austria, Cyprus, Finland, Lithuania, Portugal, Romania (Ramos et al. 2018), and Spain (Orden ARM 2656/2008; RD 907/2007; RD 638/2016).

In the European Union (EU), the Water Framework Directive (WFD) mandates that all water bodies within the EU countries should achieve good ecological or potential status by 2027 at the latest. According to the WFD, the ecological status of surface water bodies is classified as "good" when their biological elements deviate only slightly from reference conditions. Due to the importance of flow regimes for riverine biological communities, surface water bodies with significant flow alterations are unlikely to have a good ecological status (Acreman and Ferguson 2010). Thus, even if the WFD does not use the term "environmental flows" explicitly, their implementation is considered to be a key measure for the achievement of the environmental objectives of the Directive (Ramos et al. 2018).

Despite the significant development in science and legislation related to $\mathrm{EF}$, there is still limited progress in actually implementing them (Horne et al. 2017; Le Quesne et al. 2010). In this context, Hardwood et al. (2017, 2018) analyzed and compared the processes of implementation of $\mathrm{EF}$ in eight countries and formulated several recommendations in order to facilitate effective EF implementation. 
Ramos et al. (2018) documented the progress made in fourteen EU Member States during the past decade in relation to the inclusion of EF in their national water policy and their implementation. To date, there are no specific studies that systematically analyze the implementation of EF across different regions within a given country. Our work aims at filling this gap, by defining a methodological framework for the assessment of EF at a country level and applying it to Spain. Specifically, our objective has been to assess the EF implementation at River Basin District (RBD) level.

EF have been extensively studied in Spain in the last decades. Most studies have focused on different methodological aspects (Alcázar and Palau 2010; Alcázar et al. 2008; Belmar et al. 2011; García de Jalón 2003; MartinezCapel 2000; Martinez-Capel 2008, 2009; Palau and Alcázar 1996; Paredes-Arquiola et al. 2013, 2014), while few others have explored the linkages between EF and sediment dynamics (García de Jalón et al. 2017a) or the potential of experimental floods (Magdaleno 2017). The economic implications of EF on the hydropower sector in the Northeast of Spain (Bardina et al. 2015) and the interest of applying the "polluter pays principle" to environmental costs of water flow regulation (García de Jalón et al. 2017b) have also been studied. Finally, a recent research project has analyzed legal, methodological, and environmental aspects of EF considering climate change scenarios (Baeza et al. 2018).

Spain offers an illustrative example to assess EF for at least two reasons. First, Spain has a diverse climate and a broad variety of river types whose flows are often heavily altered by the existing water demands (García de Jalón et al. 2019; Vicente-Serrano et al. 2017) and increasingly affected by climate and land use changes. Thus, actions to reduce the impact of river flow alteration are needed in order to recover and protect freshwater ecosystems. And second, during the past decade the Spanish River Basin Management Plans (RBMPs) established EF in most river-type water bodies, thus providing an interesting test bed for this water management measure.

\section{Methodological Framework}

The methodological framework used in this study is inspired by the principles of adaptive management. Adaptive management seeks to improve management decisions of a given resource based on the knowledge generated through the implementation of specific management measures (Allen et al. 2011). This approach has been used in a broad range of environmental management contexts (McCook et al. 2010; Summers et al. 2015; Van Wilgen and Biggs 2011). Related with water resources, adaptive management has been applied to river flow management (Smith 2011; Warner et al. 2014), and as a general framework for improving the effectiveness of river restoration projects (Angelopoulos et al. 2017). Adaptive management is considered to be a suitable approach to improve the implementation of EF (Webb et al. 2018) and was included in the Spanish water legislation (Orden ARM 2656/2008) and in some RBMPs (CHCOC 2015; CHCOR 2015) in relation with EF.

Following the adaptive management components, our framework is structured in four steps of analysis (Fig. 1): (1) problem definition, which is essential to set goals and objectives (Summers et al. 2015); (2) design of the EF, where the specific objectives and the actions for their achievement are defined; (3) EF application; and (4) EF monitoring and evaluation, which is crucial to understand the response of the ecosystem and improve management decisions (Allen et al. 2011). For each of these steps we formulated specific questions aiming at understanding the internal coherence of the design of EF and whether the implementation corresponds to the set objectives:

(1) Problem definition. What is the ecological status of the surface water bodies in the study area? What are the significant pressures that affect the ecological status and the hydrological regime? Are the magnitude and characteristics of the hydrological alteration known?

(2) Design of the EF. To what extent are the main objectives of the EF connected to the problem identified? Are the actions proposed and their specific objectives coherent with the main objective?

(3) EF application. To what extent is the EF application coherent with its design?

(4) EF monitoring and evaluation. Is the application of EF monitored? Are the outcomes of the EF assessed? Is that information used to revise and refine the EF?

\section{Data Sources and Analysis}

The study was based on the analysis of official documents (national regulations, RBMPs, the annual reports informing about the RBMP application), as well as data retrieved from the archives of the Ministry of Environmental Affairs (MITECO in Spanish) (Table 1).

The selection of the national regulation (Orden ARM 2656/2008; RD 907/2007; RD 638/2016) was based on an extensive word search in the Spanish national official bulletin where national laws are published and by consulting several environmental lawyers. The RBMPs of 15 River Basin Districts (RBDs) corresponding to the 2015-2021 planning period were analyzed as they 
Fig. 1 Environmental Flow Evaluation Framework. The large circles represent the different phases of the assessment. The small circles represent the questions to be answered in each of the phases of analysis

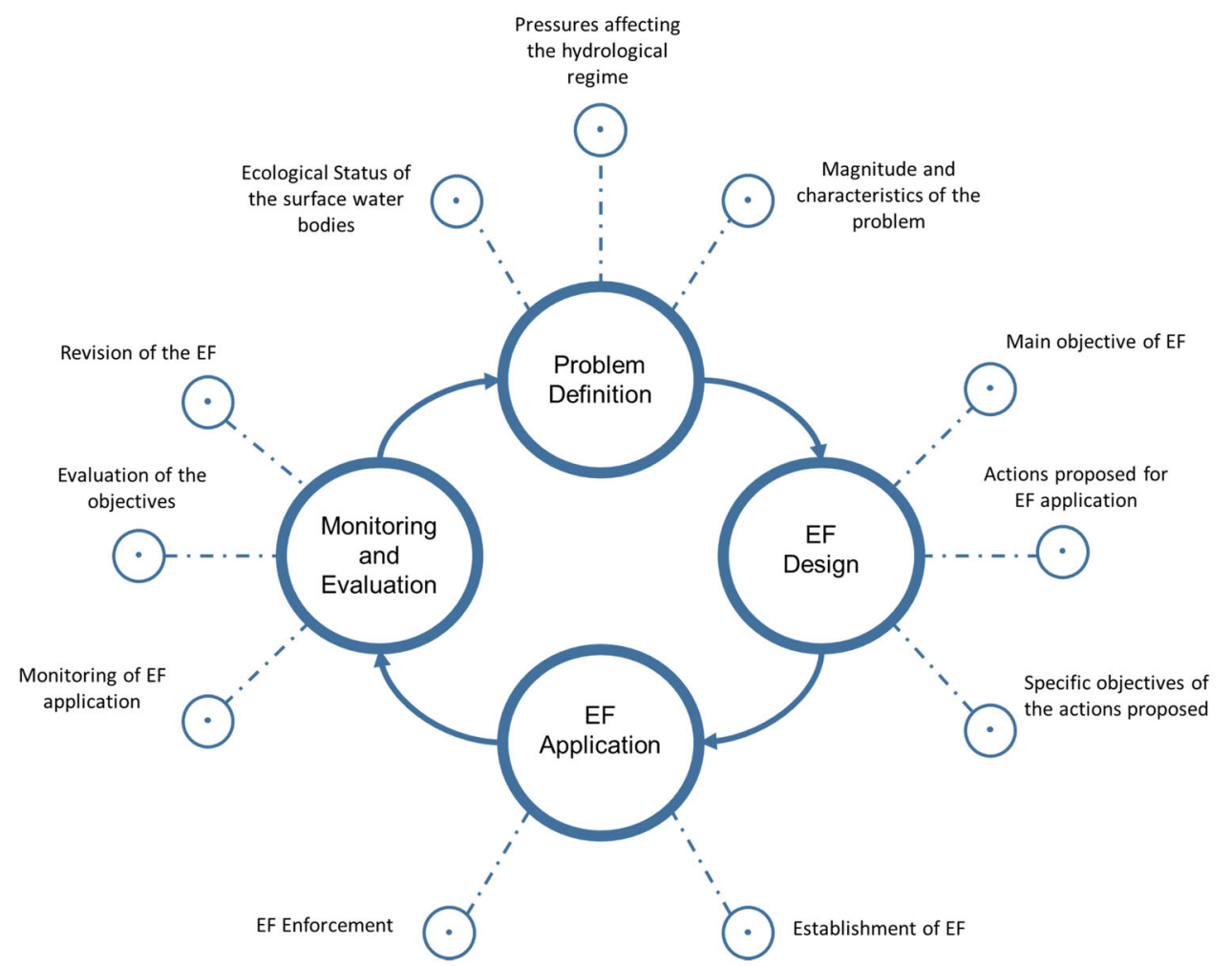

describe the process of definition of the EF that are currently being applied. We also collected all the publicly available annual reports about the RBMP application process at RBD level.

In our analysis we included three variables: simulated natural flows for the period 1980/81-2005/06 for each water body, the minimum EF established in the RBMPs and the intra-annual variability for both. The analysis started from the retrieval of average annual natural flows generated by MITECO (2015) using SIMPA, a conceptual and quasi-distributed precipitation-runoff model (Estrela and Quintas 1996; Ruíz 1998). Since EF are defined at a specific point of each water body (e.g., at the beginning, at the end, and in the middle, depending on the RBD), the simulated flow data had to be aggregated to estimate the average annual natural runoff in those specific locations in the river. Outliers resulting from this aggregation were removed using the Tukey's test (Tukey 1977). Both datasets were combined in order to (a) calculate the ratio established minimum flows vs simulated annual average flows, expressed as a percentage; and (b) compare the intra-annual variability of both variables using the coefficient of variation and the variation range between annual maximum and minimum of both variables. This analysis was carried out by water body and then aggregated at RBD and country levels.

\section{The Study Area}

Spain is divided into 25 RBDs, which include 4390 rivertype water bodies with a total length of about $77,000 \mathrm{~km}$ (MITECO 2015). This paper focuses on the river-type water bodies of the 15 RBDs located in the Spanish peninsular territory, corresponding to $98 \%$ of the Spanish surface rivertype water bodies $(N=4295)$. Location and average annual rainfall of the studied RBDs are shown in Fig. 2.

Irrigated agriculture demands about $80 \%$ of the available water resources, followed by domestic supply for about 46 million inhabitants (16\%), and industrial uses (4\%) (DGA and CEDEX 2018). The Northern regions have quite regular precipitation patterns and an average annual rainfall around $1000 \mathrm{~mm} / \mathrm{yr}$, while the rest of the country has long dry summers and an average annual rainfall ranging between 20 and $650 \mathrm{~mm} / \mathrm{yr}$ (Fig. 2). Due to the high variability of precipitation patterns, Spanish rivers are regulated by 1225 large dams (MITECO 2018a) with a total surface water storage capacity of $56,074 \mathrm{hm}^{3}$ (MITECO 2018b).

Following the WFD requirements, hydrological planning follows 6-year cycles $(2009-15 ; 2015-21 ; 2021-27)$ where each River Basin Authority (RBA) elaborates a RBMP for their RBD. The MITECO coordinates and supervises the work of the RBAs. In RBMPs water demands and water 


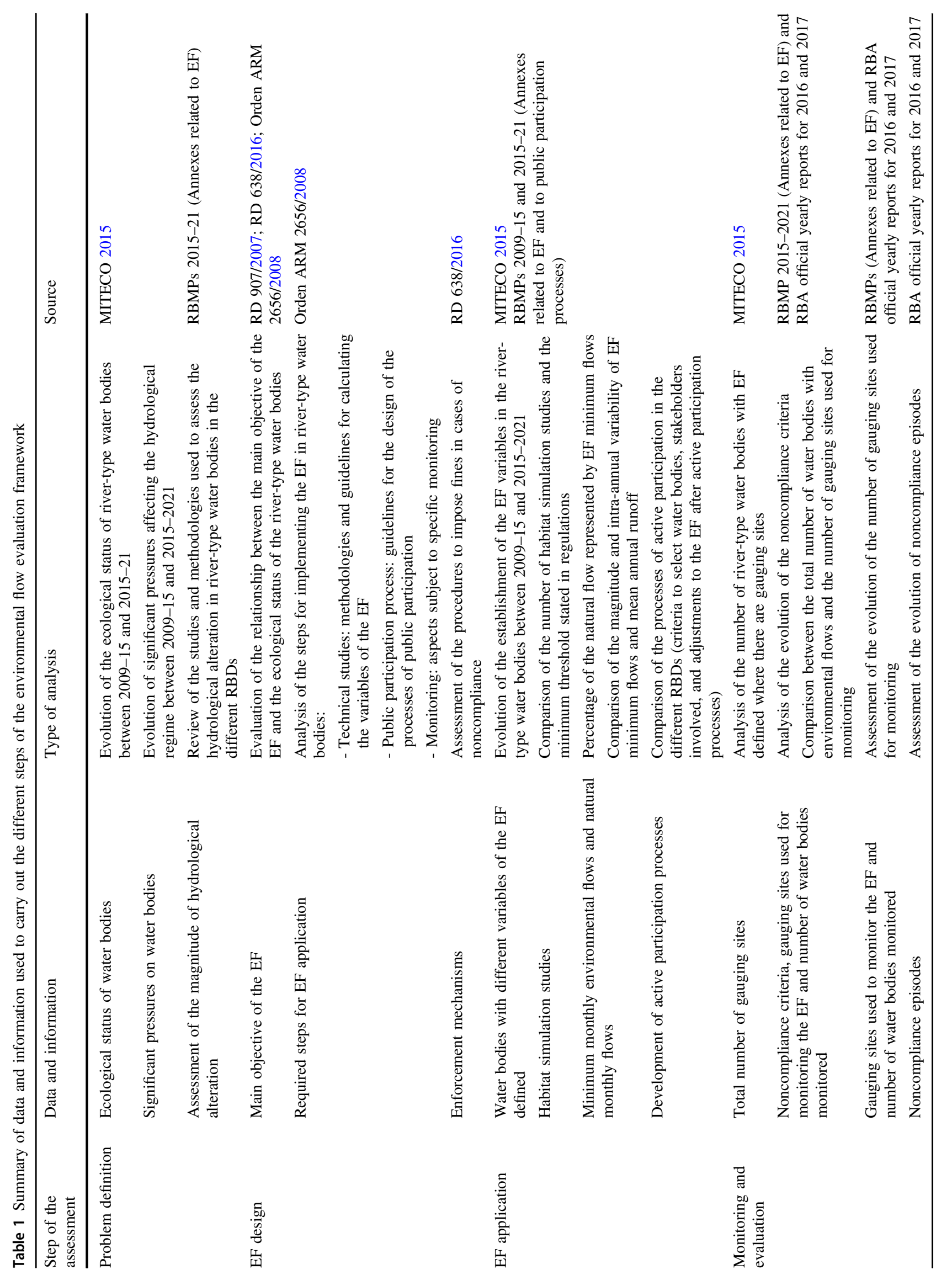


Fig. 2 Location of River Basin Districts included in the Spanish peninsular territory, showing the NW-SE geographical gradient of average annual rainfall (Modified from MITECO 2015)

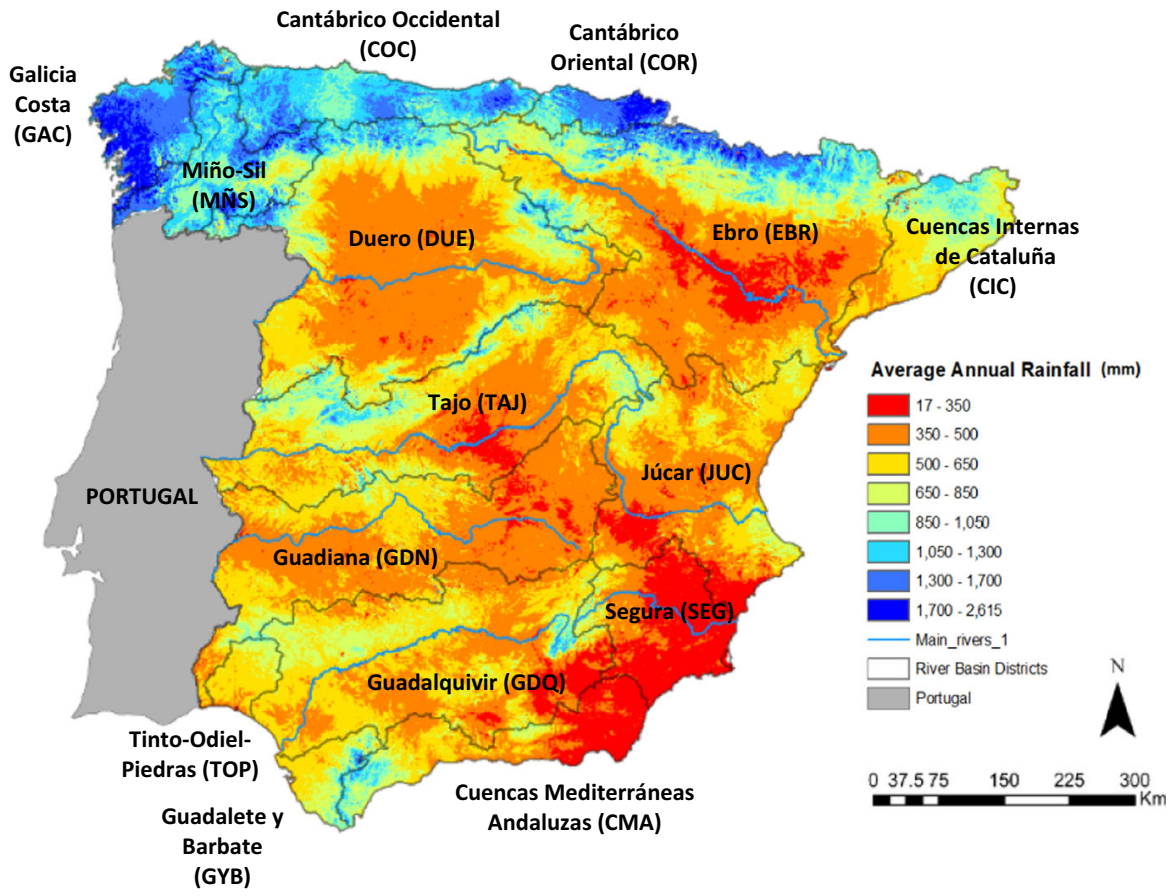

uses within each river basin are quantified and $\mathrm{EF}$ are defined for each water body as an environmental restriction on water uses (RD 907/2007).

\section{Results}

\section{Problem Definition}

Following the requirements of the WFD, RBMPs include an assessment of the status of water bodies and an inventory of the significant pressures that affect that status. Out of the five main types of significant pressures, water withdrawals and hydromorphological alterations are those that directly impact on hydrological regime.

According to the current RBMPs (2015-2021), 56\% of the surface water bodies in the studied RBDs have a status that is "good" or higher. In total, 59\% of the water bodies were found to experience hydromorphological alterations, while $30 \%$ of them are affected by water withdrawals. Between the 2009-2015 and the 2015-21 planning cycles, RBAs have improved their knowledge of the ecological status of river-type water bodies (from $15 \%$ of them with "no data" to $1 \%$ ) and of the existing pressures (inventoried hydromorphological alterations increased from 1415 to 2516; water withdrawals from 961 to 1469 ).

Spanish regulations establish that the magnitude of hydrological alteration in river-type water bodies should be calculated using indicators of hydrological alteration (IHA) (Orden ARM 2656/2008). In eleven of the fifteen assessed RBDs this type of analysis was carried out using the
IAHRIS software (IHA in RIverS) (Martinez and Fernández Yuste 2010), and in one it was performed using the IHA software (Richter et al. 1996). ${ }^{1}$ The classification of the water bodies produced by IAHRIS was refined based on expert criteria in eight RBDs.

\section{Design of the EF}

According to the Brisbane Declaration (2007, p. 3), "environmental flows describe the quantity, timing, and quality of freshwater flows and levels necessary to sustain aquatic ecosystems which, in turn, support human cultures, economies, sustainable livelihoods, and well-being". The definition of EF in the Spanish legislation focuses only the ecological facet of this management tool and links it to the EU WFD, stating that the main objective of EF is to contribute to the achievement of the good ecological status of surface water bodies (RD 907/2007; RD 638/2016; Orden ARM 2656/2008).

The Hydrological Planning Instruction issued by the Spanish Government (HPI; Orden ARM 2656/2008) requires to characterize the EF through four variables that should be determined in each RBD by the corresponding RBA for all river-type water bodies: minimum flows, maximum flows, change rates, and high flows. Maximum flows are those that should not be exceeded in the ordinary exploitation of hydraulic infrastructure while high flows are specific events of short duration such as bankfull discharges.

\footnotetext{
${ }^{1}$ No information could be found in the RBMPs about the methods used in the remaining RBDs.
} 
The legislation requires RBAs to follow four steps: (1) development of technical studies; (2) public participation; (3) application of the EF; and (4) monitoring.

\section{Technical studies}

According to the HPI, the minimum and maximum flows should be calculated applying hydrological methodologies based on representative time series of natural flow regime. The values obtained will then be adjusted by modelling the habitat suitability in representative stretches of the river. Habitat simulation studies should consider specific target species and should be carried out in at least $10 \%$ of the river-type water bodies in each RBD. The flow value identified through the hydrological method should be adjusted to the flow corresponding to a range of 50-80\% of the Weighted Usable Area (WUA) of the target species. This range could be reduced to $30-80 \%$ of the WUA if the water body is "highly hydrologically altered" or to the flow corresponding to the $25 \%$ of the WUA if a situation of prolonged drought is officially declared. The flows should be modulated following a temporal pattern that distinguishes at least two periods along the year. In the case of change rates, the HPI only specifies that their calculation should be based on hydrological series of at least 20 years. For high flows, HPI lists the elements to be calculated for its definition: magnitude, frequency, timing, seasonality, and the rates of change. The HPI also requires to carry out an assessment of the economic and social effects of EFs and their impact on levels of guarantee of water supply for existing uses.

\section{Process of public participation}

According to HPI, the objective of public participation is to make the existing water use rights compatible with the EF. The process should evaluate the technical, economic, and social viability of the EF application and should lead to the approval of an EF application and adaptive management plan. The participatory process includes three levels of involvement: public information, public consultation, and active participation. The latter level, which implies direct negotiation with water users, should be sought only when the proposed EF significantly condition water allocation in the RBD. RBAs are responsible for the selection of the water bodies that should undergo this process and of the stakeholders to be involved in the negotiation.

\section{Monitoring and evaluation}

RBAs must report annually to MITECO on the progress in the application of their RBMPs. This includes reporting on the degree of compliance with the EF (RD 907/2007) and on other aspects subject to "specific monitoring" such as: effectiveness of the implemented EF, relationship between groundwater and the EF, and evolution and degree of compliance with high flows (Orden ARM 2656/2008).

In 2016 homogenous criteria for noncompliance with the EF were legally defined for all RBDs (RD 638/2016), while prior to that date each RBA used specific noncompliance criteria in its RBD. Enforcement mechanisms to be applied in case of noncompliance are not defined. Regulations only state that the fines to be imposed should be based on the estimation of the damage caused by the noncompliance (RD 638/2016).

\section{EF Application}

\section{Technical studies}

The analysis of the 2015-2021 RBMPs reveals that the four EF variables have not been defined for all river-type water bodies $(N=4295)$. Minimum flows are set for $73 \%$ of the water bodies $(N=3140)$, while maximum flows, change rates, and high flows have been defined for $8 \%(N=362)$, $4 \%(N=179)$, and $8 \%(N=342)$ of the water bodies, respectively (Fig. 3; Table S.1).

Several authors (Arthington et al. 2006; García de Jalón 2003; Lytle and Poff 2004; Poff et al. 1997; Richter et al. 1996) remark that the well-being of riverine ecosystems is rooted in its natural hydrological regime. To know to what extent the EF are similar to the natural flow regime we compared the established EF minimum flows with simulated natural flows. After the removal of outliers, data about monthly average natural flows was obtained for 2202 water bodies, which represents $70 \%$ of the water bodies with minimum EF defined (Table 2 and Fig. 4).

The comparison revealed that the established minimum flows represent, on average, $19 \%$ of the mean annual runoff (MAR) (Table 2 and Fig. 4). In the 59\% of the simulated water bodies $(N=1304)$, the EF minimum flows represent less than the $20 \%$ of the MAR.

The intra-annual variability of the EF minimum flows, as expressed by its coefficient of variation, on average represents $45 \%$ of the intra-annual variability of unregulated flows. However, considering the difference between the maximum and minimum monthly runoff as an indicator of intra-annual variability, the established minimum flows cover on average $7 \%$ of the variability of the unregulated flow regime ( $\mathrm{RG}$ in Table 2).

In seven RBDs habitat simulation studies have been carried out in less than $10 \%$ of the river-type water bodies, which is the minimum percentage required by the HPI, with two RBMPs reporting percentages lower than 5\% (Fig. 5). 

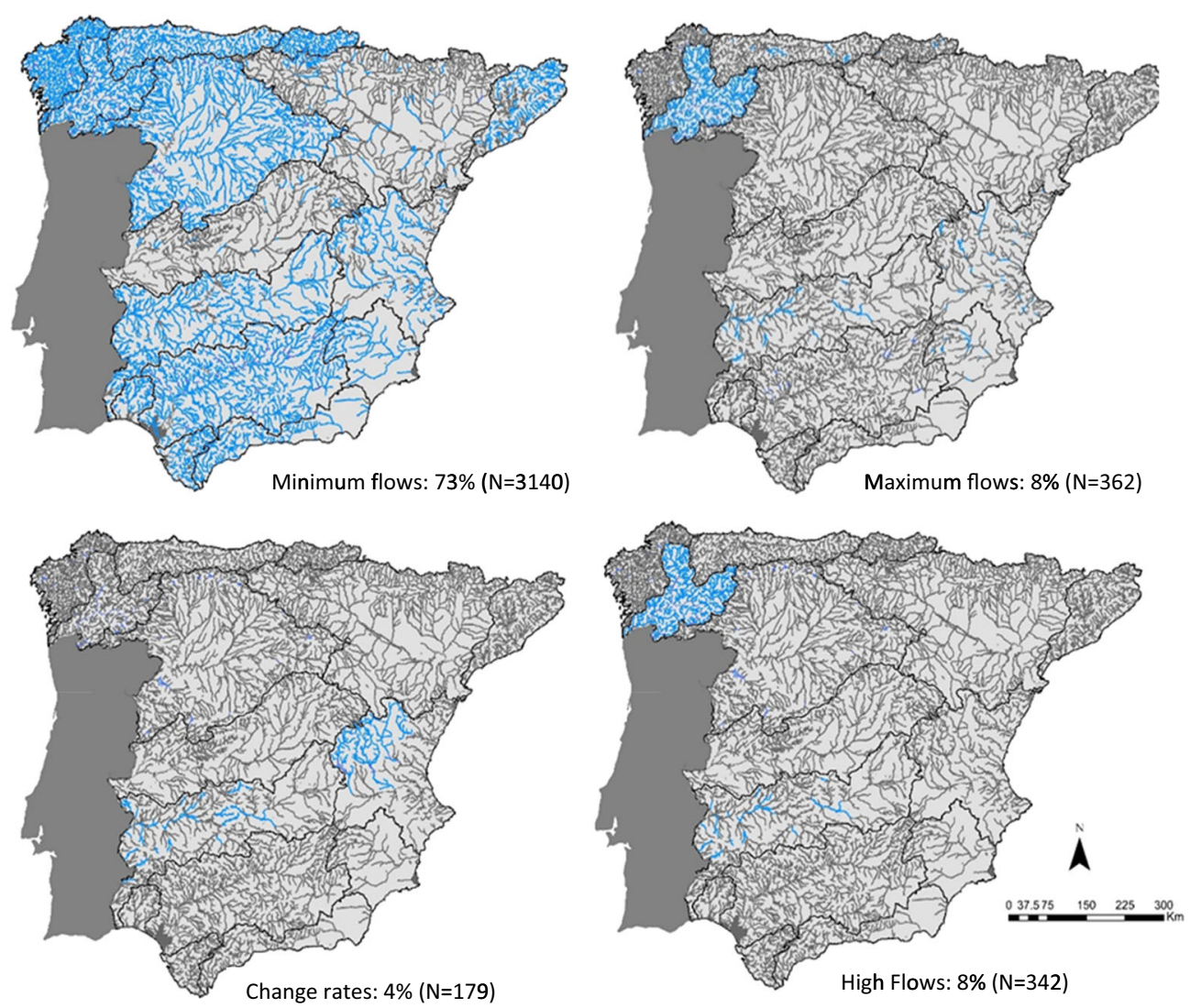

Fig. 3 River-type water bodies with environmental flow variables defined (in blue). For each EF component, the percentage and total number of river-type water bodies are indicated

\section{Public participation process}

The process of active participation has been significantly different across the assessed RBDs. According to the documents produced by the RBAs, in only three RBDsCantábrico Occidental, Cantábrico Oriental, and Cuencas Internas de Cataluña-the participatory process was designed to negotiate the adaptation of water uses to EF, as required by the Spanish regulation. In the rest of the RBDs, the negotiation process seems to have been aimed at adjusting the calculated EF taking into account the existing water uses.

As noted earlier, the RBAs had to select in which water bodies negotiations were to be undertaken. Since the selection criteria are not specified in the regulation, the procedure varied across the RBDs. For instance, RBAs of Cuencas Mediterráneas Andaluzas, Guadalete y Barbate, Guadiana, Segura and Tinto-Odiel-Piedras used their own criteria to identify "strategic water bodies", where they expect the EF application to create a conflict with preexisting uses. The Duero RBA organized a round of meetings with stakeholders to identify potentially conflictive water bodies. In two RBDs-Cantábrico Oriental and Cantábrico Occidental-the negotiation process was carried out only with the largest water users. For the remaining RBDs no information about the selection criteria could be found for this study.

Nine RBMPs informed about adjustments to the calculated EF as a result of the participation process (Fig. 6). The EF was modified after negotiation in $7 \%(N=205)$ of the water bodies with EF minimum flows. In total $86 \%(N=$ 178) of the recorded modifications implied an increase in the proposed EF minimum flows. The reasons for the EF modifications are not reported in the official documents.

\section{Monitoring and Evaluation}

At completion of this study, official yearly reports on the EF application for the hydrological years 2015-16 and 2016-17 were available only for ten RBDs in at least 1 year (Table S.2). In those RBDs, there are 905 active official river gauging sites located in river-type water bodies with $\mathrm{EF}$ defined (Fig. 7). During the first year of reporting, compliance with EF was monitored in 297 water bodies $(9 \%$ of those with EF minimum flows) and during the following year in 357 water bodies (11\%) (Table S.2). Thus, there are over 500 gauging sites that could potentially monitor EF and that are not used to measure compliance (Fig. 7). 
Table 2 Selected data about the studied RBDs

\begin{tabular}{|c|c|c|c|c|c|c|c|c|}
\hline River basin district & $\begin{array}{l}\text { Available water } \\
\text { resources } \\
\left(\mathrm{hm}^{3} / \text { year) }\right.\end{array}$ & $\begin{array}{l}\text { Total water } \\
\text { demands } \\
\left(\mathrm{hm}^{3} / \text { year) }\right.\end{array}$ & $\begin{array}{l}\text { S-WEI } \\
(\%)\end{array}$ & $\begin{array}{l}\text { Water bodies } \\
\text { simulated }^{\mathrm{a}}\end{array}$ & $\begin{array}{l}\text { \# Water bodies with } \\
\text { EF minimum } \\
\text { flow }<20 \% \text { mean } \\
\text { annual runoff }\end{array}$ & $X(\%)$ & $\mathrm{CoV}(\%)$ & $\mathrm{RG}(\%)$ \\
\hline Cantábrico Occidental & 11,855 & 484 & 4.1 & $90 \%(N=224)$ & 65 & 27 & 48 & 11 \\
\hline Cantábrico Oriental $^{\mathrm{b}}$ & 4673 & 265 & 5.7 & $80 \%(N=93)$ & 75 & 21 & 55 & 10 \\
\hline $\begin{array}{l}\text { Cuencas Internas de } \\
\text { Cataluña }\end{array}$ & 2536 & 1008 & 39.7 & $100 \%(N=248)$ & 229 & 14 & nd & nd \\
\hline $\begin{array}{l}\text { Cuencas Mediterráneas } \\
\text { Andaluzas }\end{array}$ & 2916 & 1100 & 37.7 & $74 \%(N=86)$ & 45 & 22 & 45 & 10 \\
\hline Duero & 12,777 & 3756 & 29.4 & $60 \%(N=404)$ & 209 & 21 & 37 & 7 \\
\hline Ebro & 14,340 & 8378 & 58.4 & $72 \%(N=50)$ & 47 & 12 & 47 & 5 \\
\hline Galicia-Costa & 12,716 & 338 & 2.7 & $72 \%(N=286)$ & 61 & 29 & 35 & 9 \\
\hline Guadalete y Barbate & 823 & 414 & 50.3 & $0 \%$ & nd & nd & nd & nd \\
\hline Guadalquivir & 7071 & 3771 & 53.3 & $72 \%(N=285)$ & 198 & 16 & 31 & 4 \\
\hline Guadiana & 4869 & 2358 & 48.4 & $68 \%(N=134)$ & 134 & 2 & nd & 2 \\
\hline Júcar & 3194 & 2789 & 87.3 & $64 \%(N=119)$ & 101 & 12 & 24 & 2 \\
\hline Miño-Sil & 11,823 & 403 & 3.4 & $83 \%(N=227)$ & 109 & 21 & 48 & 8 \\
\hline Segura & 1425 & 1600 & 112.3 & $36 \%(N=28)$ & 15 & 19 & 36 & 7 \\
\hline Tajo & 7865 & 3002 & 38.2 & $95 \%(N=18)$ & 16 & 12 & 33 & 3 \\
\hline Tinto-Odiel-Piedras & 801 & 468 & 58.4 & $0 \%$ & nd & nd & nd & nd \\
\hline Spain & 99,684 & 30,134 & 30.2 & $70 \%(N=2202)$ & 1304 & 19 & 45 & 7 \\
\hline
\end{tabular}

S-WEI $(\%)=$ Water Exploitation Index i.e., (Total water demands/available water resources $) \times 100 ; X(\%)=($ Average EF minimum flow/ average annual natural runoff) $\times 100 ; \mathrm{CoV}(\%)=$ (coefficient of variation of average EF minimum flow/coefficient of variation of average natural runoff $) * 100 ; \mathrm{RG}(\%)=(($ Maximum EF monthly flow-minimum EF monthly flow $) /($ maximum natural monthly runoff-minimum natural monthly runoff) $) \times 100$, referred to $\mathrm{EF}$ minimum flow

$n d$ no data

${ }^{a}$ In percentage, number of water bodies where mean annual runoff was simulated vs to the number of water bodies with EF minimum flows

${ }^{\mathrm{b}}$ Includes Basque Country Internal Basins. Water resources available, total water demands, S-WEI data obtained from DGA and CEDEX (2018)

In the 2015-16 hydrological year, episodes of noncompliance occurred in $32 \%(N=100)$ of the water bodies where minimum flows were monitored, while in 2016-17 they were reported in $40 \%(N=144)$ of them ${ }^{2}$ (Fig. 8; Table S.2). Figure 8 represents the location of the gauging sites where noncompliance episodes were recorded in 2015-16 and 2016-17. There are 65 (17\%) gauging sites where episodes of noncompliance were reported repeatedly, mostly in Miño-Sil RBD (30 episodes of noncompliance in 2016 and in 2017). In both years, noncompliance was attributed mostly to below average natural runoff or no explanation was provided.

No information was found in the reports about fines imposed in order to enforce the EF or about other aspects that should be included in the monitoring reports according to the HPI (EF effectiveness, the relationship between groundwater and $\mathrm{EF}$ and the evolution and degree of compliance with high flows).

\footnotetext{
${ }^{2}$ It should be noted that compliance criteria changed between those reporting periods.
}

\section{Discussion}

The RBMPs required by the WFD (based on 6-year planning cycles) are particularly suitable for the application of an adaptive management approach to the definition and implementation of EF, as the lessons learned in one cycle can inform adjustments in the following planning cycle (Webb et al. 2018). Compared with assessments at larger scales (Hardwood et al. 2018; Ramos et al. 2018), the analysis of the process of implementation of EF at country level carried out in this study offers specific insights for EF improvement.

\section{Definition and Magnitude of the Problem}

During the past decade, the Spanish RBAs have worked intensively on the assessment of ecological status in the river-type water bodies, which has now been characterized in $99 \%$ of the water bodies. Moreover, they made important efforts in order to improve the official inventory of 


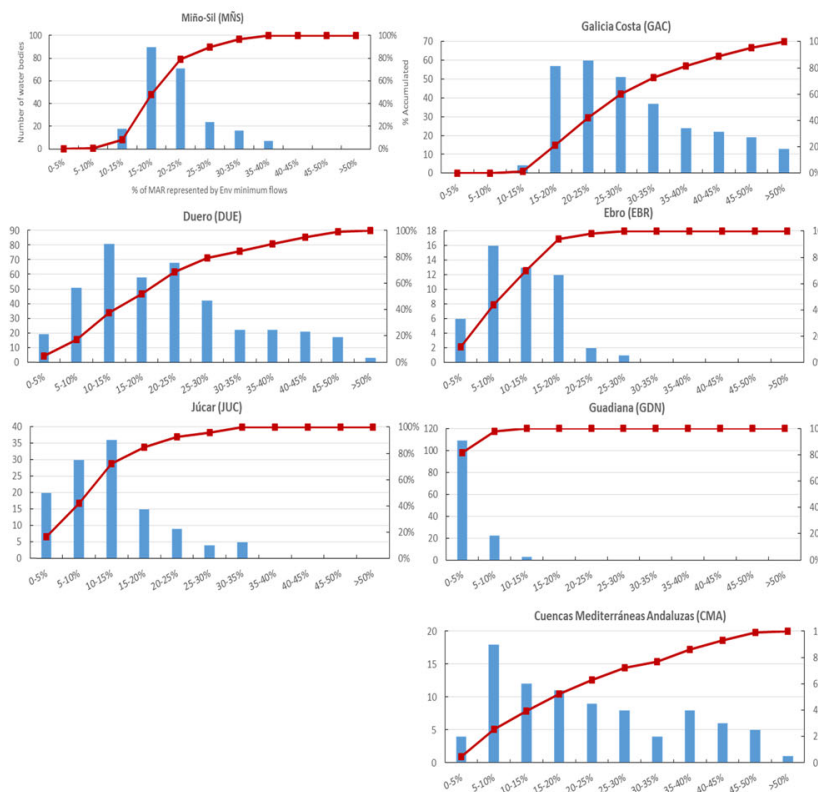

Fig. 4 Minimum flows established in each river-type water body expressed as percentage of the mean natural annual runoff (horizontal axis) in the different Spanish RBMPs. Vertical axis indicate the frequency of river-type water bodies with the corresponding minimum

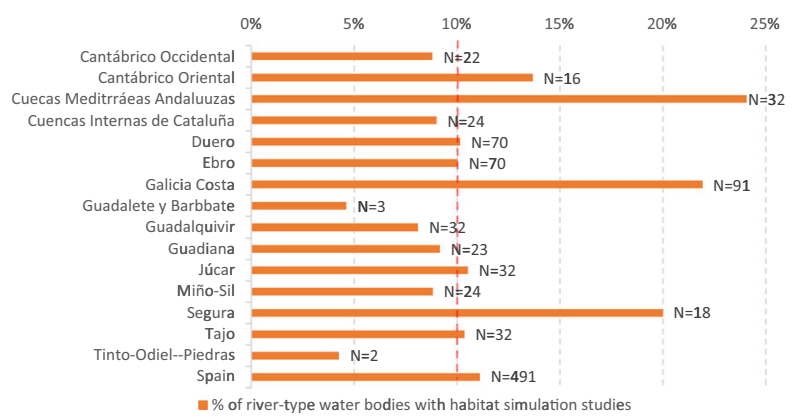

Fig. 5 Percentage of river-type water bodies with habitat simulation studies in each RBD. $N$ : number of habitat simulation studies. Red dotted line: minimum percentage established by the HPI

pressures on water bodies (MITECO 2017) and to quantify the magnitude of the hydrological alterations in Spanish rivers.

This diagnosis of the problem however has several limitations. The assessment of the status was performed without using fish- and phytoplankton-related indicators in most RBDs, except for Júcar and Cuencas Internas de Cataluña (DGA and CEDEX 2018). This might have led to an overestimation of the number of water bodies classified as having a good ecological status. The accuracy of the current classification of alteration of the hydrological regime has been questioned, e.g., due to the uncertainty of the input data (CHJ 2015; EC 2015), to the inability to detect shorttime-scale hydrological alterations (e.g., hydropeaking) (CHJ 2015; CHGAC 2015; EC 2015), or because groundwater-surface water interactions are only indirectly

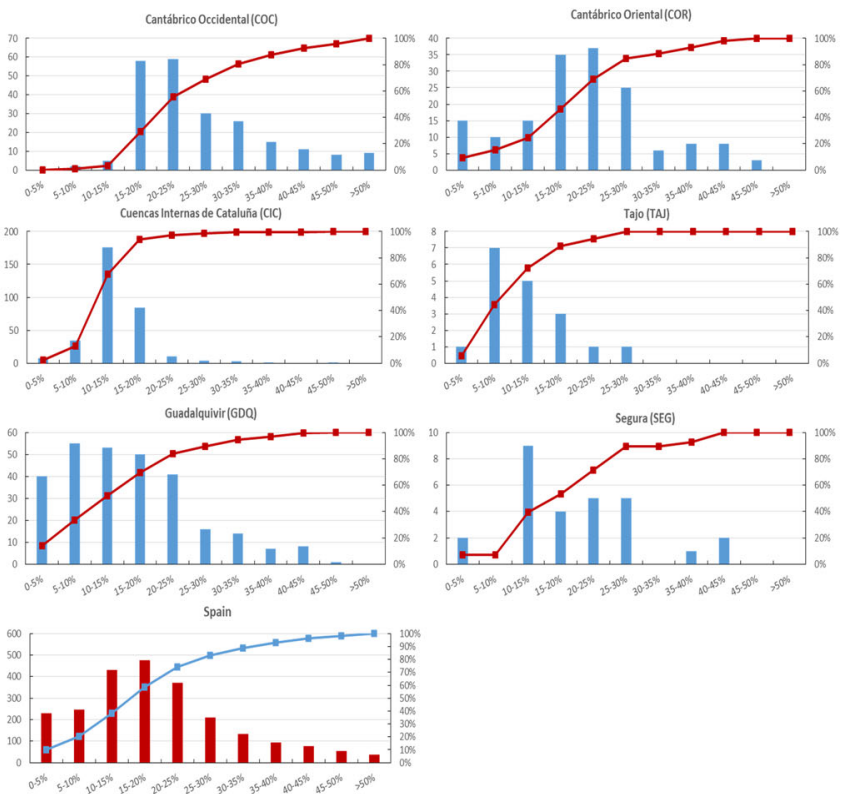

flow in absolute number of water bodies (left axis) and in \% of water bodies (right axis). Red line shows cumulative values of river-type water bodies. Data of natural flows obtained from MITECO (2015)

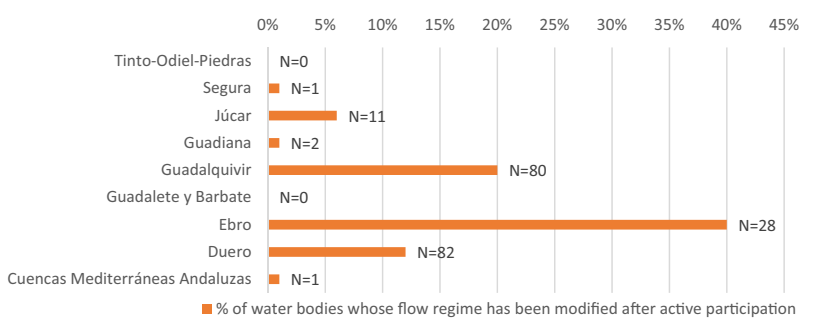

Fig. 6 Water bodies where EF were adjusted after negotiation with stakeholders, percentages refer to the water bodies with established minimum flows

considered in the analysis (EC 2015). The RBMPs do not include a specific analysis to explain and quantify the causal links between pressures and status at water body level, which should be at the basis of the design of any corrective measure, including EF. This important gap points to a methodological challenge that is still under study in the scholarly literature, where different methods to assess this kind of connections are being developed (e.g., Feld et al. 2016; Gebler et al. 2018).

\section{EF Design}

The Spanish legislation explicitly links the main objective of EF to the improvement of the ecological status of rivers, which is consistent with the EC recommendations (EC 2015). However, the capacity of EF to provide cultural, social, and economic benefits, as highlighted in several EF definitions (Brisbane Declaration 2007; Moore 2004), is not 
Fig. 7 Gauging sites in water bodies (WB) with EF minimum flows set in 2016-17 $(N=905)$. In green, gauging sites used for EF monitoring $(N=390)$. In black, gauging sites not used for EF monitoring $(N=515)$. The striped RBDs are those with no available official yearly reports
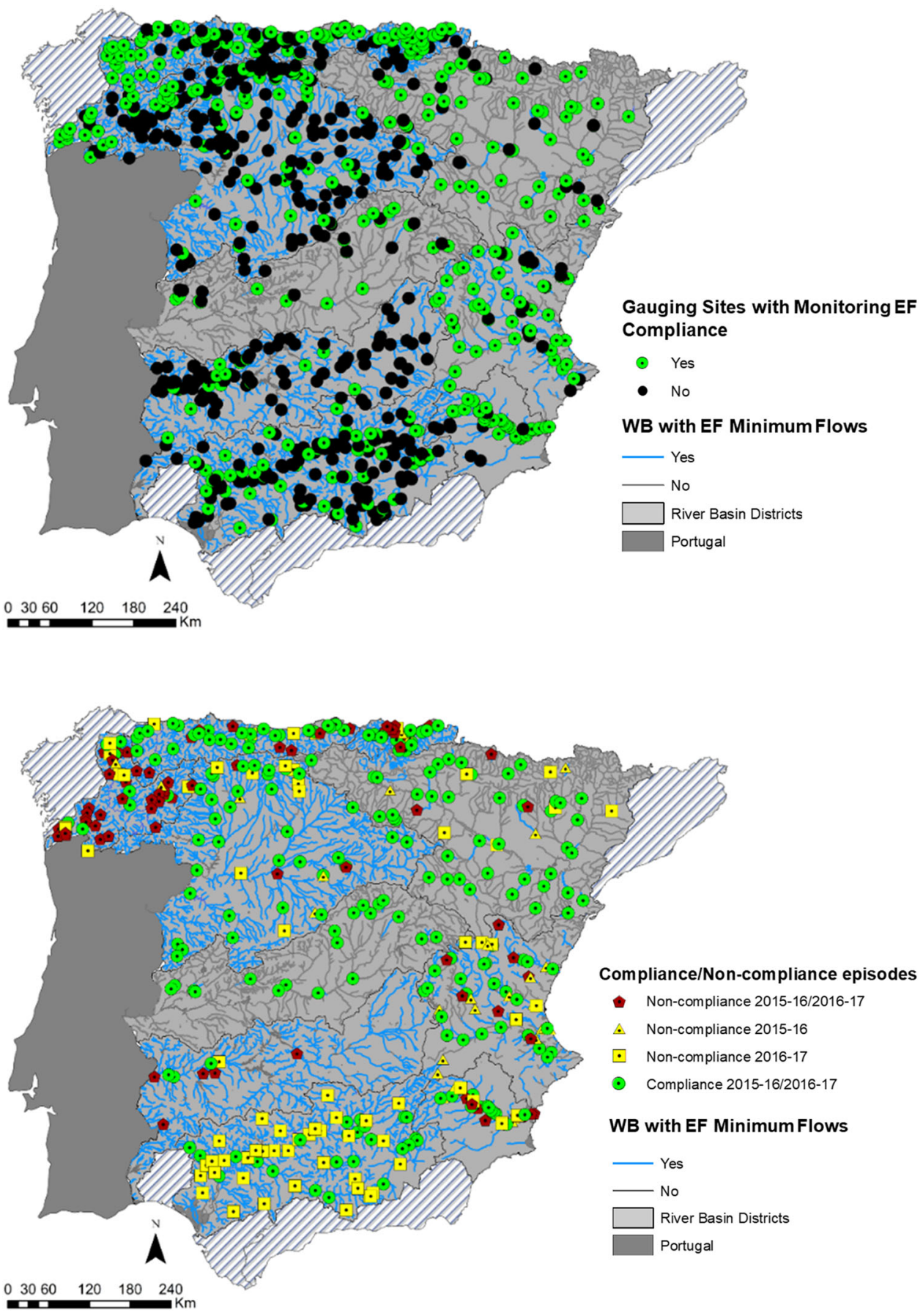

Fig. 8 Compliance and noncompliance episodes in gauging sites used for EF monitoring. For Tajo RBD, compliance data were available only for the 2015-2016 period; for Guadalquivir RBD they were available only for the 2016-2017 period of riverine ecosystems (Arthington et al. 2006; Lytle and Poff 2004; Poff et al. 1997; Richter et al. 1996) are limited. The use of biologically significant periods of different species to define relevant seasonal patterns could make significant contributions to the design of EF. This approach has been already applied in several rivers in Spain (García de Jalón 2003; Paredes-Arquiola et al. 2013; Solans and García de Jalón 2016).

Second, some important methodological choices that shape the EF calculation seem to be grounded in practical 
constraints (e.g., lack of time or economic resources) rather than in scientific reasons. These include the requirement for RBAs to carry out habitat simulation studies in "at least $10 \%$ " of the RBD's water bodies and the specification to adjust flows obtained by hydrological methods to a range of $50-80 \%$ of the WUA or even $30-80 \%$ in water bodies that have been classified as "highly hydrologically altered". In particular, the latter criterion implies relaxing EF requirements in water bodies that are particularly in need of ambitious EF in order to revert flow regime alteration. We also observed that although Spanish legislation establishes that minimum flows could be reduced if the RBA declares a situation of prolonged drought, an increase in the EF is not foreseen in case of wet years. The differentiation among these three situations (dry, average, and wet years) is recommended as a way to increase the resilience of freshwater ecosystems (EC 2015; Baeza et al. 2018) and should be included in the design of habitat simulation studies (Bovee et al. 1998).

Third, the definition of the EF is not based on the establishment of an explicit link between flow alteration and ecological responses at water body level, but rather on the application of a similar calculation approach to all the water bodies. While this case-by-case approach can be time consuming and methodologically challenging, it would help adjust EF to the actual needs of the water body and thus better contribute to the achievement of its good status. For instance, the "Ecological Limits of Hydrological Alteration" (ELOHA) framework could be applied to a regional scale (Poff et al. 2010). This framework has been applied in the Ebro River Basin (Solans and García de Jalón 2016) and it requires a previous hydrological classification of rivers that has already been made at river basin scale in the Segura River Basin (Belmar et al. 2011) and at national scale (Peñas and Barquín 2019; García de Jalón et al. 2019). These scholarly efforts could significantly help in defining EF that adjust to specific hydrological river-type water body classes.

Fourth, the existing monitoring programs do not include an evaluation of the effectiveness of $\mathrm{EF}$ to improve the ecological status of the water body. The design of monitoring programs that improve the understanding of the relationships between different aquatic species and changes in the hydrological regime has been a common challenge (Souchon et al. 2008). This has been also observed in most of the European countries where EF have been implemented (Ramos et al. 2018). Several authors have developed frameworks to assess flow-ecological response relationships that can inform RBAs about the ecological effects of EF (Souchon et al. 2008; Webb et al. 2015). The selection of appropriate ecological indicators within suitable timeframes is essential to improve our understanding about flow and ecology relationships (King et al. 2015). The European
Commission (EC 2015) has recommended the use of shortand long-term indicators. The first ones consider hydromorphological elements that are expected to have a rapid response to the application of an $\mathrm{EF}$ an include the variation in depth and width of the river channel, the structure and substrate of the riverbed and the longitudinal and transversal continuity of the river. Long-term indicators measure the response of ecosystems to modification of the hydrological regime: e.g., floodplain indicators (changes in spatial extent, distribution of native floodplain forest/wetland vegetation communities, or changes in species composition or abundance of floodplain bird species, etc.) and riverine indicators (changes in abundance, biomass, age structure, and spatial extent of flow-sensitive fish or invertebrate species, etc.) (Higgins et al. 2011 in EC 2015). The calculation of these long-term indicators requires systematic and periodical data collection campaigns that should be part of the EF monitoring program.

Finally, monitoring should not be limited to ecological outcomes. Some authors (Harwood et al. 2018; King et al. 2015) have highlighted the need to monitor and document social and economic outcomes of EF implementation. Such monitoring can demonstrate the benefits of EF to stakeholders, politicians, and the general public, thus helping gain public support.

\section{Application of EF}

In most of the water bodies the establishment of EF focused only on the definition of minimum flows. However, the three other variables foreseen in the Spanish regulation do play a crucial role in the maintenance of aquatic ecosystems. For instance, maximum flows and high flows are critical in sediment dynamics (García de Jalón et al. 2017a), in the maintenance of the lateral connectivity between the floodplain and the riverbed and to control the presence of alien species (O'Keeffe and Le Quesne 2009). Magdaleno and Fernández (2011) demonstrated that high water releases during the dry season (e.g., to meet irrigation demands) caused significant alteration of floodplain vegetation and the associated erosion dynamics in the main stem of the Ebro river. The changes induced by anthropic activities in this river have caused the alteration and near elimination of the free meander dynamics (Ollero 2010). Several authors concluded that the lack of high flows in rivers are related to the loss of riverine habitats (Petts and Gurnell 2005; Tockner et al. 2010). Thus, a greater effort should be made to calculate and apply all those EF variables.

During the last decades, the Spanish RBAs have made advances in the methodologies used for EF assessment. Spain has moved from methodologies based on historical flow records where ecological aspects were not considered 
(e.g., 10\% mean annual flow or flow frequency distribution) to more complex techniques such as habitat simulation methodologies (García de Jalón 2003). The use of environmental objectives based on static rules such as maintaining $20 \%$ of the MAR (Smakhtin et al. 2004), omit the fundamental role of flow variability in the maintenance of the riverine ecosystem and will almost certainly lead to ecosystem degradation (Bunn and Arthington 2002; Poff et al 1997). Even using 20\% of MAR as static threshold, the EF minimum flows represent less than the $20 \%$ of the MAR in 1304 river-type water bodies ( $42 \%$ of river-type water bodies with minimum flows) (Table 2 and Fig. 4). Moreover, the low variation between the maximum and minimum of the established minimum flows suggests the need to significantly improve intra-annual variability of EF. Moreover, seven RBDs do not reach the minimum percentage of habitat simulation studies required by the regulations $(10 \%$ of the RBD's river-type water bodies). Thus, the calculation of EF would benefit from an increase in the number of habitat simulation studies in order to better adjust the results of hydrological methods.

Limitations exist not only in the scope of EF but also in the data available for their calculation. The existence of significant gaps in historical flow records is a recurrent constraint in the characterization of the hydrological regime in natural conditions using gauged data (Moore 2004). In Spain, the lack of natural flow data (Belmar et al. 2011) led to the widespread use of the SIMPA model in Spain (Baeza et al. 2018). This model underestimates low flows, a basic parameter for the establishment of the minimum base flows (Baeza et al. 2018), which can have a cascading effect on the quality of the calculations of EFs.

Our study has shown that the approach to public involvement has been quite heterogeneous across the RBDs. Since several authors underscore the important role of public participation in the success of EF (Hardwood et al. 2017; Le Quesne et al. 2010; Moore 2004; Webb et al. 2018), it would be interesting to carry out a systematic, indepth analysis of the participatory processes across the RBDs in order to learn from the past experience.

\section{Monitoring and Evaluation}

As acknowledged by adaptive management, monitoring is crucial to iteratively adjust management strategies based on past performance (Allen et al. 2011). King et al. (2015) highlight that monitoring programs of EF should measure river's ecological responses to EF application. Currently, monitoring programs in Spain do not include an evaluation about EF effects on ecological parameters, which is a clear area of improvement.

EF monitoring programs currently focus on the degree of compliance with EF and data are collected in only $11 \%$ of river-type water bodies where minimum flow is defined. There are over 515 additional gauging sites that potentially could be suitable to monitor compliance with EF. Thus, it would be useful to analyze the factors that could explain this circumstance e.g. how many water bodies are represented by each gauging site, the number of hydrological and morphological river types present in the RBD, or the lack of an adequate measuring system at the gauging site. This could serve as a starting point for expanding and upgrading the existing monitoring network. Monitoring is also critical for ensuring accountability of water users in case of noncompliance and to set a sound basis for future assessments. According to the available data, there have been episodes of noncompliance of $\mathrm{EF}$ in $40 \%$ of the water bodies monitored during 2015-16 and 2016-17. Furthermore, multiple noncompliance episodes in the same water bodies (Fig. 8) can point to the need to apply enforcement measures such as fines to the responsible water users or the need for additional complementary actions to avoid further ecosystem deterioration. This requires not only specific data collection activities but also an in-depth analysis of the reasons for noncompliance.

\section{Conclusions}

The Spanish legislation states that the main objective of EF is to contribute to the achievement of good ecological status of surface water bodies. Thus, the definition of the EF makes explicit reference to the achievement of this fundamental outcome. When moving from theory to practice, however, several shortcomings jeopardize the ability of the established EF to mitigate the impact of flow regulation by dams and other hydraulic infrastructure over the ecological status of Spanish rivers. These include: (1) in most water bodies EF define only minimum flows, and do not consider maximum flows, change rates, and high flows; (2) the established minimum flows are lower than the $20 \%$ of the MAR in over a half the of the water bodies with EF; (3) habitat simulation methods to calculate EF have been applied in a very limited number of water bodies; (4) intraannual variability of the defined EF is absent or very low, leading to the homogenization of flows across the year; (5) active involvement of stakeholders is rarely used as a means to adapt existing uses to the $\mathrm{EF}$ as required in the legislation; and (6) the EF monitoring program has a limited geographical scope and does not assess the ecological response to $\mathrm{EF}$, which is fundamental to improve the effectiveness of this key management tool.

Acknowledgements This study was funded by a research grant provided by the Botín Foundation and Tatiana Pérez de Guzmán El Bueno Foundation. The authors thank the editor and two anonymous 
reviewers for their constructive feedback of the paper; Alberto Garrido and Antonio Bolinches for their valuable comments and Guillermo Reboreda for his assistance with data preprocessing.

\section{Compliance with Ethical Standards}

Conflict of Interest The authors declare that they have no conflict of interest.

Publisher's note Springer Nature remains neutral with regard to jurisdictional claims in published maps and institutional affiliations.

\section{References}

Acreman MC, Dunbar MJ (2004) Defining environmental flow requeriments? a review. Hydrology and Earth System Sciences Discussions, European Geosciences Union, 861-876

Acreman MC, Ferguson AJD (2010) Environmental flows and the European Water Framework Directive. Freshw Biol 55:32-48. https://doi.org/10.1111/j.1365-2427.2009.02181.x

Alcázar J, Palau A (2010) Establishing environmental flow regimes in a Mediterranean watershed based on a regional classification. $\mathrm{J}$ Hydrol 388(1-2):41-51

Alcázar J, Palau A, Vega-Garcı C (2008) A neural net model for environmental flow estimation at the Ebro River Basin, Spain. J Hydrol 349(1-2):44-55

Allen CR, Fontaine JJ, Pope KL, Garmestani AS (2011) Adaptive management for a turbulent future. $\mathrm{J}$ Environ Manag 92:1339-1345. https://doi.org/10.1016/j.jenvman.2010.11.019

Angelopoulos NV, Cowx IG, Buijse AD (2017) Integrated planning framework for successful river restoration projects: Upscaling lessons learnt from European case studies. Environ Sci Policy 76:12-22. https://doi.org/10.1016/j.envsci.2017.06.005

Arthington AH, Bunn SE, Poff NL, Naiman RJ (2006) The challenge of providing environmental flow rules to sustain river ecosystems. Ecol Appl 16:1311-1318

Baeza SD, Gallego BMS, Herrera GT, La Calle MA, Martínez FJ (2018) Caudales ecológicos: valoración de experiencias en las cuencas españolas y propuestas adaptativas frente al cambio climático. Proyecto Q-Clima. Fundación Nueva Cultura del Agua. Zaragoza, España

Bardina M, Honey-Rosés J, Munné A (2015) Implementation strategies and a cost/benefit comparison for compliance with an environmental flow regime in a Mediterranean river affected by hydropower. Water Policy 18:197-216. https://doi.org/10.2166/wp.2015.169

Belmar O, Velasco J, Martinez-Capel F (2011) Hydrological classification of natural flow regimes to support environmental flow assessments in intensively regulated Mediterranean Rivers, Segura River Basin (Spain). Environ Manag 47:992. https://doi. org/10.1007/s00267-011-9661-0

Bovee KD, Lamb BL, Bartholow JM, Stalnaker CB, Taylor J, Henriksen J (1998) Stream habitat analysis using the instream flow incremental methodology. Geological Survey Reston Biological resources Div, Springfield, Virginia

Brisbane Declaration (2007) Environmental flows are essential for freshwater ecosystem health and human well-being. In 10th International River Symposium, pp 3-6. Brisbane, Australia

Bunn SE, Arthington AH (2002) Basic principles and ecological consequences of altered flow regimes for aquatic biodiversity. Environ Manag 30(4):492-507

Plan Hidrológico de la Demarcación Hidrográfica de Galicia Costa. Confederación Hidrográfica de Galicia Costa-CHGAC (2015) Anexo IV. Caudales ecológicos. España
Plan Hidrológico de la Demarcación del Cantábrico Occidental. Confederación Hidrográfica del Cantábrico Occidental—CHCOC (2015) Anexo V. Caudales ecológicos. España

Plan Hidrológico de la Demarcación del Cantábrico Oriental. Confederación Hidrográfica del Cantábrico Oriental-CHCOR (2015) Anexo V. Caudales ecológicos. España

Plan Hidrológico de la Demarcación del Júcar. Confederación Hidrográfica del Júcar-CHJ (2015) Anexo V. Caudales ecológicos. Apéndices IV, V y VI. España

Dirección General del Agua y Centro de Estudios y Experimentación de Obras Públicas-DGA y CEDEX (2018) Síntesis de los Planes Hidrológicos Españoles: Segundo ciclo de la DMA (2015-2021). Ministerio para la Transición Ecológica, Centro de Publicaciones, Madrid, España

Estrela T, Quintas L (1996) El sistema integrado de modelización precipitación-escorrentía SIMPA. Revista Digital del CEDEX, 104, 43-43. Madrid, España

European Commission - EC (2015) Ecological flows in the implementation of the water framework directive Guidance Document $\mathrm{n}^{\circ} 31$. European Union publications office, Luxemburg

Feld CK, Segurado P, Gutiérrez-Cánovas C (2016) Analysing the impact of multiple stressors in aquatic biomonitoring data: a 'cookbook'with applications in R. Sci Total Environ 573:1320-1339

García de Jalón D (2003) The Spanish experience in determining minimum flow regimes in regulated streams. Canadian. Water Resour Manag 28:185-198

García de Jalón D, Bussettini M, Rinaldi M, Grant G, Friberg N, Cowx IG, Magdaleno F, Buijse T (2017a) Linking environmental flows to sediment dynamics. Water Policy 19:358-375

García de Jalón S, González del Tánago M, Alonso C, García de Jalón D (2017b) The environmental costs of water flow regulation: an innovative approach based on the 'Polluter Pays' principle. Water Resour Manag 31:2809-2822

García de Jalón S, González del Tánago M, García, de Jalón D (2019) A new approach for assessing natural patterns of flow variability and hydrological alterations: the case of the Spanish rivers. J Environ Manag 233:200-210

Gebler D, Wiegleb G, Szoszkiewicz K (2018) Integrating river hydromorphology and water quality into ecological status modelling by artificial neural networks. Water Res 139:395-405

Harwood A, Johnson S, Richter B, Locke A, Yu X, Tickner D (2017) Listen to the river: lessons from a global review of environmental flow success stories. WWF, UK

Harwood A, Tickner D, Richter B, Locke A, Johnson S, Yu X (2018) Critical factors for water policy to enable effective environmental flow implementation. Front Environ Sci 6:37

Higgins JV, Konrad CP, Warner A, Hickey JT (2011) A framework for monitoring, reporting and managing dam operations for environmental flows. Version 1.0. SRP measures working group. https://www.conservationgateway.org/Documents/SRP\% 20Monitoring\%20Document\%20-\%202011-02-11.pdf

Horne AC, Webb JA, O'Donnell E, Arthington AH, McClain M, Bond N, Acreman M, Hart B, Stewardson MJ, Richter B, Poff NL (2017) Research priorities to improve future environmental water outcomes. Front Environ Sci 5:89

Jiménez JA (2005) Conceptualización de caudal ambiental en Costa Rica: determinación inicial para el Río Tempisque. UICN

King AJ, Gawne B, Beesley L, Koehn JD, Nielsen DL, Price AJ (2015) Improving ecological response monitoring of environmental flows. Environ Manag 55:991-1005

Le Quesne T, Kendy E, Weston D (2010) The implementation challenge: taking stock of government policies to protect and restore environmental flows. The Nature Conservancy, UK

Lytle DA, Poff NL (2004) Adaptation to natural flow regimes. Trends Ecol evolution 19:94-100 
Magdaleno F (2017) Experimental floods: a new era for Spanish and Mediterranean rivers? Environ Sci Policy 75:10-18

Magdaleno F, Fernández JA (2011) Hydromorphological alteration of a large Mediterranean river: relative role of high and low flows on the evolution of riparian forests and channel morphology. River Res Appl 27:374-387

Martinez C, Fernández Yuste J (2010) IAHRIS Índices de Alteración Hidrológica en Ríos. Versión 2.2. Manual de usuario y Manual de referencias metodológicas. Universidad Politécnica de Madrid. Madrid, España

Martinez-Capel F (2000) Preferencia de microhábitat de Barbus bocagei, Chondrostoma polylepis y Leuciscus pyrenaicus en la cuenca del río Tajo. Tesis Doctoral. Tesis doctoral. Escuela Técnica Superior de Ingenieros de Montes de la Universidad Politécnica de Madrid, Madrid

Martinez-Capel F, García de Jalón D, Werenitzky D, Baeza SD, Rodilla-Alamá M (2009) Microhabitat use by three endemic Iberian cyprinids in Mediterranean rivers (Tagus River Basin, Spain). Fish Manag Ecol 16(1):52-60

Martinez-Capel F, Parada M, Mascarell AB, Munné T (2008) Nose velocity calculation for spatial analysis of habitat and environmental flow assessments. 4th ECRR International Conference on River Restoration, Venezia, Italy

McCook LJ, Ayling T, Cappoo M, Choat JH, Evans RD, De Freitas DM, Marsh H (2010) Adaptive management of the Great Barrier Reef: a globally significant demonstration of the benefits of networks of marine reserves. Proc Natl Acad Sci, 107(43): 18278-18285

Ministerio para la Transición Ecológica-MITECO (2015) Recuperado de https://www.miteco.gob.es/es/cartografia-y-sig/ide/desca rgas/default.aspx

Ministerio para la Transición Ecológica-MITECO (2017) Síntesis de los planes hidrológicos españoles. Segundo ciclo de la DMA (2015-2021) (Borrador. Versión 2.82). Madrid, España

Ministerio para la Transición Ecológica-MITECO (2018a) Recuperado de https://sig.mapama.gob.es/93/ClienteWS/snczi/default. asp ? origen $=8 \&$ nombre $=$ PRESA_ESTADISTICA_4\&claves $=$ \&valores=

Ministerio para la Transición Ecológica-MITECO (2018b) Recuperado de https://www.miteco.gob.es/es/prensa/ultimas-noticias/lareserva-hidr\%C3\%A1ulica-espa\%C3\%B1ola-se-encuentra-al523-por-ciento-de-su-capacidad/tcm:30-483552

Moore M (2004) Perceptions and interpretations of environmental flows and implications for future water resource management: a survey study. Linköping University, Sweden

O'Keeffe J, Le Quesne T (2009) Keeping rivers alive. A primer on environmental flows and their assessment. WWF Water Security Series 2. Gland, Switzerland

Ollero A (2010) Channel changes and floodplain management in the meandering middle Ebro River, Spain. Geomorphology 117 (3-4):247-260

Orden ARM/2656/2008, de 10 de septiembre, por la que se aprueba la Instrucción de Planificación Hidrológica. Boletín Oficial del Estado (BOE-A-2008-15340), de 22 de septiembre de 2008, núm. 229, España. https://www.boe.es/eli/es/o/2008/09/10/arm2656

Palau A, Alcázar J (1996) The basic flow: an alternative approach to calculate minimum environmental instream flows. In: Proceedings of 2nd International Symposium on Habitat Hydraulics. pp 547-558. Quebec, Canada

Paredes-Arquiola J, Martinez-Capel F, Solera A, Aguilella V (2013) Implementing environmental flows in complex water resources systems-case study: the Duero river basin, Spain. River Res Appl 29:451-468

Paredes-Arquiola J, Solera A, Martinez-Capel F, Momblanch A, Andreu J (2014) Integrating water management, habitat modelling and water quality at the basin scale and environmental flow assessment: case study of the Tormes River, Spain. Hydrological Sci J 59(3-4):878-889

Peñas FJ, Barquín J (2019) Assessment of large-scale patterns of hydrological alteration caused by dams. J Hydrol 572:706-718

Petts GE, Gurnell AM (2005) Dams and geomorphology: research progress and future directions. Geomorphol 71:27-47

Poff NL, Allan JD, Bain MB, Karr JR, Prestegaard KL, Richter B, Sparks RE, Stromberg JC (1997) The natural flow regime: a paradigm for river conservation and restoration. BioScience 47:769-784

Poff NL, Richter B, Arthington AH, Bunn SE, Naiman RJ, Kendy E, Acreman M, Apse C, Bledsoe BP, Freeman MC, Henriksen J, Jacobson RB, Kennen JG, Merritt DM, O'Keeffe J, Olden JD, Rogers K, Tharme RE, Warner A (2010) The ecological limits of hydrologic alteration (ELOHA): a new framework for developing regional environmental flow standards. Freshw Biol $55: 147-170$

Ramos V, Formigo N, Maia R (2018) Environmental flows under the WFD implementation. Water Resour Manag 32:5115-5149

Real Decreto-RD 638/2016, de 9 de diciembre, por el que se modifica el Reglamento del Dominio Público Hidráulico aprobado por el Real Decreto 849/1986, de 11 de abril, el Reglamento de Planificación Hidrológica, aprobado por el Real Decreto 907/2007, de 6 de julio, y otros reglamentos en materia de gestión de riesgos de inundación, caudales ecológicos, reservas hidrológicas y vertidos de aguas residuales (BOE-A-2016-12466). España. https://www. boe.es/eli/es/rd/2016/12/09/638

Real Decreto-RD 907/2007, de 6 de julio, por el que se aprueba el Reglamento De Planificación Hidrológica. Boletín Oficial del Estado (BOE-A-2007-13182), de 7 de julio, núm. 162, España. https://www.boe.es/eli/es/rd/2007/07/06/907

Richter B, Baumgartner JV, Powell J, Braun DP (1996) A method for assessing hydrologic alteration within ecosystems. Conserv Biol 10:1163-1174

Ruíz JM (1998) Desarrollo de un modelo hidrológico conceptual distribuido de simulación continua integrado con un SIG. Universidad Politécnica de Valencia. Valencia, España

Smakhtin V, Revenga C, Döll P (2004) A pilot global assessment of environmental water requirements and scarcity. Water Int 29 (3):307-317

Smith CB (2011) Adaptive management on the central platte river-science, engineering, and decision analysis to assist in the recovery of four species. J Environ Manag 92:1414-1419

Solans MA, García de Jalón D (2016) Basic tools for setting environmental flows at the regional scale: application of the ELOHA framework in a Mediterranean river basin. Ecohydrology 9 (8):1517-1538

Souchon Y, Sabaton C, Deibel R, Reiser D, Kershner J, Gard M, Katopodis C, Leonard P, Poff NL, Miller WJ, Lee Lamb B (2008) Detecting biological responses to flow management: missed opportunities; future directions. River Res Appl 24(5):506-518

Summers M, Holman I, Grabowski RJ (2015) Adaptive management of river flows in Europe: a transferable framework for implementation. J Hydrol 531:696-705

Tockner K, Pusch M, Borchardt D, Lorang MS (2010) Multiple stressors in coupled river-floodplain ecosystems. Freshw Biol 55:135-151

Tukey JW (1977) Exploratory data analysis. Addison-Wesley, Reading

Van Wilgen B, Biggs HC (2011) A critical assessment of adaptive ecosystem management in a large savanna protected area in South Africa. Biol Conserv 144:1179-1187

Vicente-Serrano SM, Zabalza-Martínez J, Borràs G, López-Moreno JI, Pla E, Pascual D, Savé R, Biel C, Funes I, Martín-Hernández N, Peña-Gallardo M (2017) Effect of reservoirs on streamflow and river regimes in a heavily regulated river basin of Northeast Spain. Catena 149:727-741 
Warner A, Bach LB, Hickey JT (2014) Restoring environmental flows through adaptive reservoir management: planning, science, and implementation through the Sustainable Rivers Project. Hydrol Sci J 59:770-785

Webb JA, Little SC, Miller KA, Sterwardson MJ, Rutherfurd ID, Sharpe AK, Patulny L, Poff NL (2015) A general approach to predicting ecological responses to environmental flows: making best use of the literature, expert knowledge, and monitoring data. River Res Appl 31(4):505-514

Webb JA, Watts RJ, Allan C, Conallin JC (2018) Adaptive management of environmental flows. Environ Manag 61 (3):339-346 